\title{
ON THE ROLE OF THE KIDNEY DURING NEPHROTIC EDEMA: POTASSIUM EXCRETION AND SODIUM RETENTION ${ }^{1}$
}

\author{
By JACK METCOFF, NOBUYUKI NAKASONE, ${ }^{2}$ aNd C. PHILLIPS RANCE 3 wITH \\ THE TECHNICAL ASSISTANCE OF AUDREY ANDREWS AND MARIE HELMICK \\ (From the Department of Pediatrics, Harvard Medical School, and the Children's Medical Center, \\ Boston, Mass.)
}

(Submitted for publication September 24, 1952; accepted October 22, 1953)

In the nephrotic syndrome, loss of plasma protein and resulting reduction of colloid osmotic (oncotic) pressure in the presence of sustained hydrostatic pressure could cause an accumulation of interstitial fluid $(1,2)$. This simple hypothesis, however, neither accounts for periodic release of edema fluid nor for other features of the nephrotic syndrome which suggest disturbance of the organization of intracellular fluid. To what extent is the kidney implicated? An obvious approach to this question is the examination of renal responses during edema and during diuresis, keeping in mind the possibility that abnormal circumstances other than hypoproteinemia may be operating behind the kidney and require alteration of the usual pattern of renal control of removal of water and electrolytes in the urine.

The retention of sodium and water with accumulation of edema fluid exemplifies this alteration of renal regulation. However, it is the purpose of this report to suggest that during nephrotic edema sodium retention may represent a homeostatic response conditioned by many factors, among them the failure of cells properly to transport or retain potassium. In this sense, sodium retention may be an effective compensatory alteration rather than a disorder of kidney function.

Twenty years ago other workers ( 3 ) indicated the existence of two schools of thought concerning nephrotic edema: one emphasized the importance of specific kidney or tissue disturbances in the production of defective electrolyte regulation; the other maintained that fluid retention and abnormal electrolyte behavior could be explained solely on

1 This study was supported by grants from the National Institutes of Health, U.S.P.H.S., Bethesda, Maryland.

2 Postdoctorate Research Fellow of the National Institutes of Health, 1950-52.

8 Fellow of the Kellogg Foundation, 1950-51. Present address : Hospital for Sick Children, Toronto, Ont. the basis of plasma protein deficit and resultant decrease in oncotic pressure. They found that although quantitative adjustment to sodium loads was limited in the nephrotic patient, qualitative similarity of sodium balance during brief periods of oral electrolyte loading was found in a nephrotic and normal subject; they therefore suggested that the data do not support the concept advocated by Widal and Javal (4) of specific renal defects in the excretion of chloride, or, as suggested later by Magnus-Levy (5) and Blum and Van Caulaert (6), of sodium. Other balance studies in edematous nephrotic patients emphasized that the retention of sodium and chloride loads, administered for longer periods of time, was in proportion to the extracellular fluid concentrations of these ions $(7,8)$. These observations were considered to provide further support for the oncotic hypothesis.

As a result of more precise measurements of kidney functions, the net retention of ingested or infused sodium is thought to result from limitation of sodium excretion and has been explained on the basis of a "glomerulo-tubular imbalance" (9, 10). This hypothesis suggests that either reduced filtration, permitting prolonged contact of the filtrate with normally active tubular cells, or excessive tubular activity relative to the level of glomerular filtration, or both, lead to excessive reabsorption of water and solutes.

The qualitative similarity of ion excretion by the normal subject and by the nephrotic patient has continued to be generally accepted. The quantitative limitation of sodium excretion by the nephrotic patient is usually considered to be a manifestation of impaired kidney function. Recent observations have indicated that the dynamic renal responses in nephrotic patients to intravenous sodium loads may be neither qualitatively nor quantitatively similar to those of normal subjects, since the sodium loads resulted in excessive potassium 


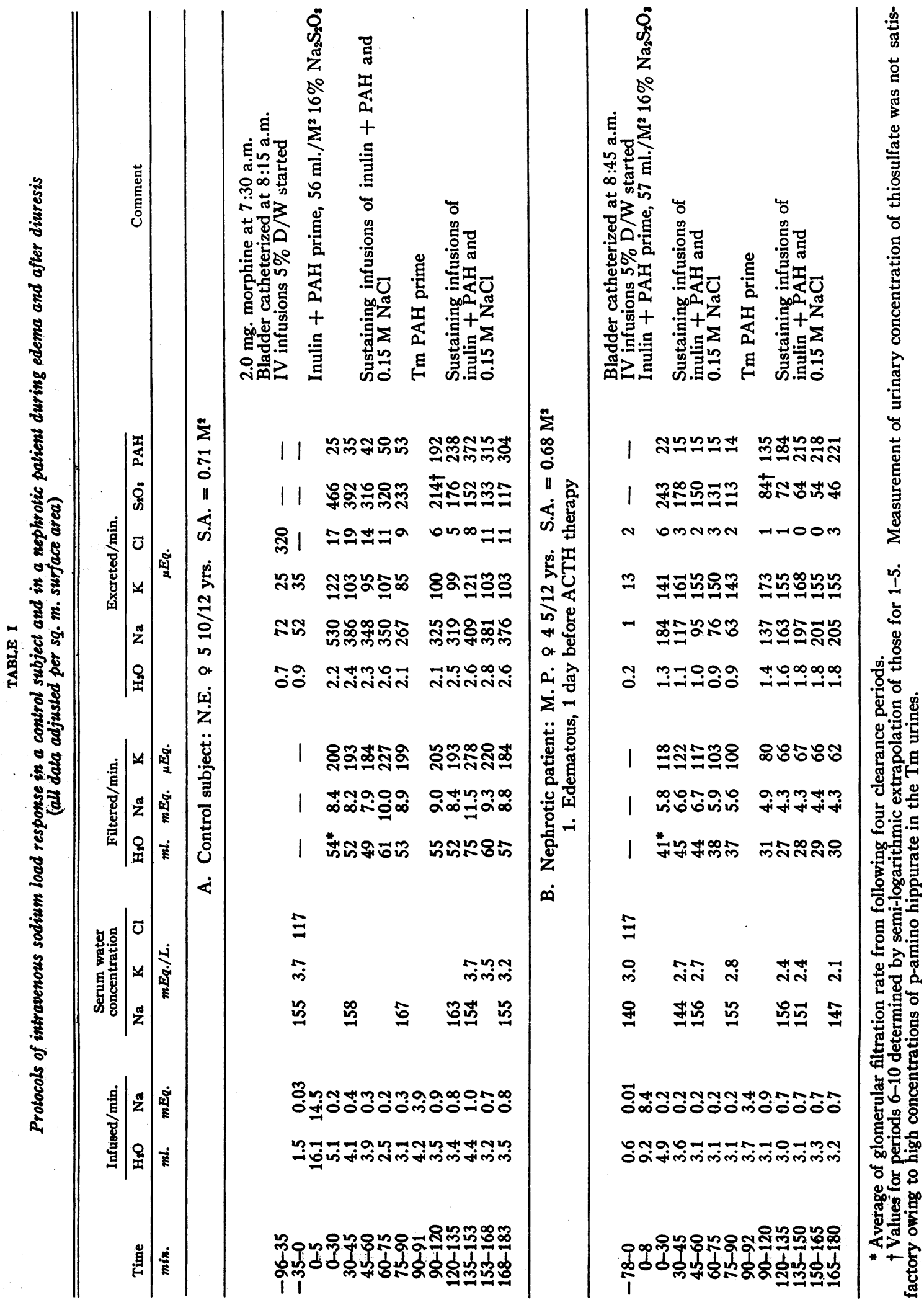


ROLE OF THE KIDNEY IN NEPHROTIC EDEMA

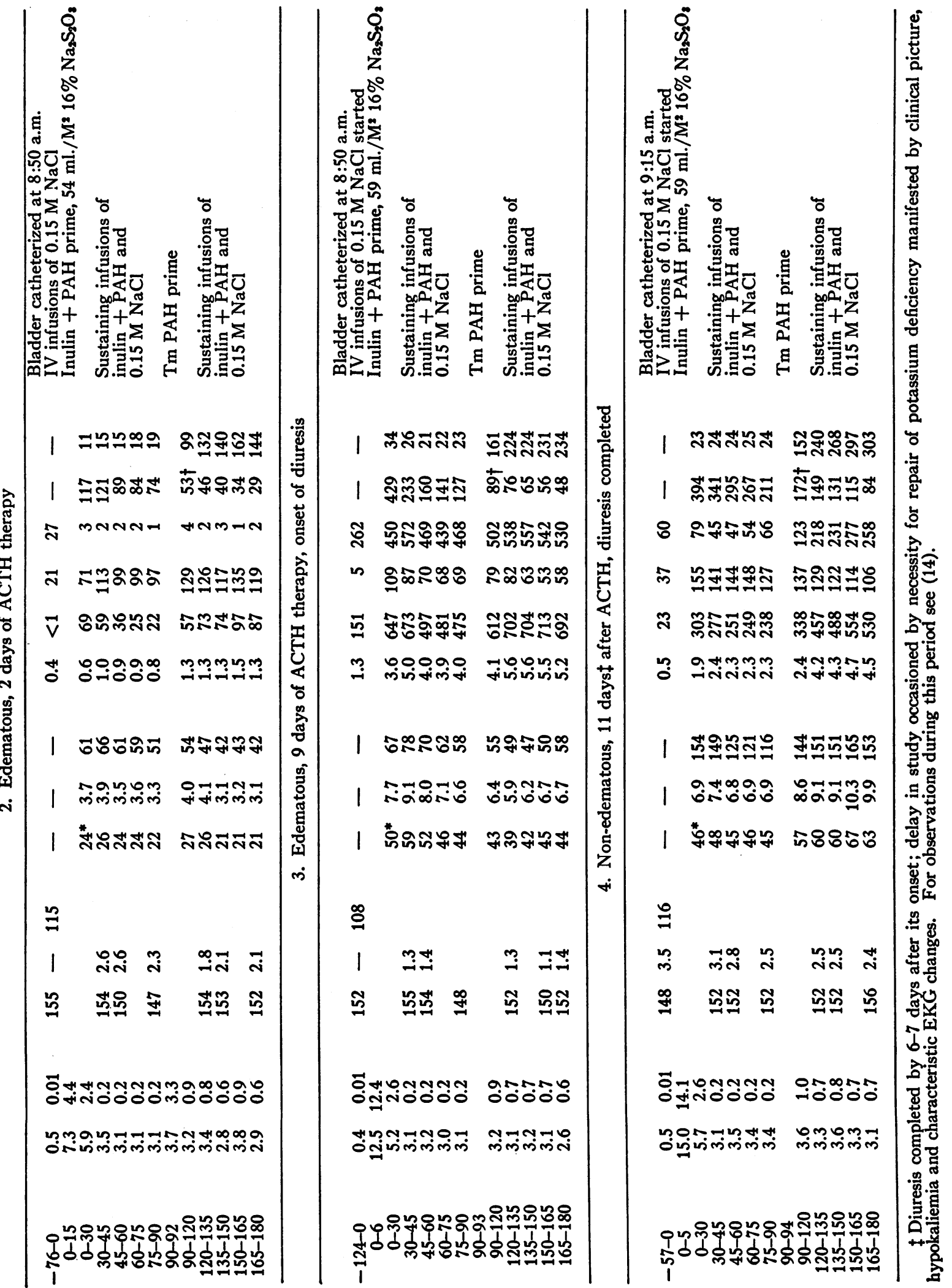


excretion by the edematous nephrotic patients and not by normal subjects $(11,12)$.

In order to re-examine the mechanisms of excretion of sodium, potassium, and water in the nephrotic syndrome, infusion of a sodium plus non-reabsorbable anion load was chosen as a device for promoting active renal tubular transport of these ions and water. A large quantity of non-reabsorbable anion in the luminal fluid requires chemically equivalent amounts of cations and limits the reabsorption of water. Under these conditions cations may be provided by secretion of hydrogen or potassium ions, or by a decreased reabsorption of sodium. Since the renal capacity to excrete large quantities of hydrogen ion during this type of load is rather limited, the excretion of sodium and potassium is rapidly augmented.

When the sodium salt of a non-reabsorbable anion is infused in the normal subject, the anion is promptly excreted with an almost equivalent amount of sodium (13-16). Since the edematous nephrotic patient has some limitation in the rapid excretion of sodium, it might be expected that a non-reabsorbable anion load would place the cellular cation exchange mechanisms in the renal tubule under stress. If the limitations to excretion of sodium were not overcome, presumably markedly increased potassium excretion would result. Some of the excreted potassium might be derived from the intracellular compartment (17, 18). Since depletion of potassium content (of muscle and kidney) (19) is thought to occur in the nephrotic syndrome, further sacrifice of this intracellular ion to meet cation requirements for solute excretion would suggest either some predominant factor obligating sodium reabsorption or a defect in cellular economy favoring potassium loss. If excessive potassium excretion depended upon excessive sodium reabsorption as a result of "glomerulo-tubular imbalance," this effect might be expected to disappear during and following diuresis when glomerular filtration rate rises and sodium excretion is abundant.

Accordingly, observations on effects of intravenous sodium loading were made over a threeweek period in the same nephrotic children during accumulating edema; during administration of a ten-day course of adrenocorticotrophic hormone (ACTH) which produces an almost predictable diuresis in a large proportion of nephrotic children
$(20,21)$; at the onset of diuresis ; and finally, when non-edematous. The studies were designed:

1) To compare the excretions of sodium, potassium, and water in the nephrotic with those observed in normal subjects under similar loading conditions;

2) to determine whether the tendency to excessive potassium excretion was the result of increased sodium reabsorption;

3 ) to relate renal and extrarenal transfers of potassium; and

4) to determine whether alterations of ion transport by the kidney might represent either (a) effective function in defense of body composition in the presence of a primary glomerular membrane lesion, plasma albumin loss, and simultaneous changes in body tissue cell structure and function, or $(b)$ impaired kidney function.

Control subjects were studied for comparative purposes.

\section{METHODS}

Three control "normal" 4 and four nephrotic 5 children were studied. All subjects had been confined to bed and each consumed an ordinary hospital diet without added salt ( 1 to $2 \mathrm{Gm}$. $\mathrm{NaCl}$ per day) for at least four days. The nephrotic patients had been on similar diets prior to hospitalization and were in a phase of accumulating edema. Food, but not water, was restricted for 12 hours preceding the studies which were carried out in the morning at approximately the same time in each instance. Patients were premedicated with morphine sulfate ( 1.3 to $4 \mathrm{mg}$.) to lessen apprehension. Clearance and excretion studies were carried out by the usual techniques. The bladder was catheterized. Inulin and p-aminohippurate clearances were used as indicators of glomerular filtration and renal plasma flow, respectively. After the initial clearance priming doses of inulin and p-aminohippurate were administered, a single injection of approximately 10 per cent thiosulfate $\left(\mathrm{Na}_{2} \mathrm{~S}_{2} \mathrm{O}_{3} \cdot 5 \mathrm{H}_{2} \mathrm{O}\right)$ in distilled water calculated to provide 60 to $80 \mathrm{mM} \mathrm{Na}$ per $\mathrm{M}^{2}$ was infused in three to six minutes and served as the initial sodium load. After a 30-minute "equilibration" period, four 15minute urine collection periods were obtained. A priming and sustaining infusion for TmPAH, which served as a

4 These children had been hospitalized on the Orthopedic service for a variety of diseases. None had clinical evidence of renal diseases.

- Simultaneous occurrence of anasarca, hyperlipemia, hypoproteinemia, and proteinuria were considered pathognomonic of the nephrotic syndrome. Because of previous observations (22) no further attempt at classification was made. 
second sodium plus non-reabsorbable anion load, was then administered with inulin and collections repeated according to the same schedule. After withdrawal of the control blood specimen anaerobically, subsequent blood specimens were obtained from a second indwelling needle, through which $0.15 \mathrm{M} \mathrm{NaCl}$ was being infused slowly, ${ }^{6}$ at approximately $30,60,90,120,150$, and 180 minutes. Since repeated venipunctures were not required, the children usually remained calm during the three to four hour study period. The children were not premedicated with potassium salts, and the infusate solutions were potassium-free.

Urines were collected in volumetric cylinders and volumes including wash estimated to $0.1 \mathrm{ml}$. Standard methods of analysis for inulin (23), p-aminohippurate (24), and thiosulfate (25) were used with some micromodifications. Sodium and potassium were measured on an internal standard flame photometer (26), and chloride in urine by a modified Volhard technique (27). Electrolyte composition of the infused solutions was determined by analysis. Serum proteins were measured by micro Kjeldhal analysis. Serum carbon dioxide content was determined manometrically (28), and $\mathrm{pH}$, colorimetrically (29).

\section{CALCULATIONS}

Surface area was taken as the most reasonable basis for comparison of subjects and was estimated from a nomogram constructed from the DuBois formula using height and weight. In edematous nephrotic children height and post-diuresis, non-edematous weight were used in surface area calculations in order to afford a better estimate of metabolic mass. Non-edematous weights were obtained at the time of the last study in each patient.

Corrections for serum water and binding equilibria. All analytic serum values were corrected for calculated water content derived from the total serum protein concentration and binding equilibria.

Serum water was estimated from the total serum protein concentration according to the formula:

$\left[\mathrm{H}_{2} \mathrm{O}\right]$ serum $(\mathrm{Gm}$. per L. $)=990-0.8$ [Serum Protein (Gm. per L.)].

Gibbs-Donnan and other effects which modify the movements of solutes across a semi-permeable membrane and exert a constraining effect on movement of the solvent are here considered under the term "binding equilibria." Equilibrium factors are unknown for sodium, potassium, and other ions in the presence of the abnormal serum protein of sera from a patient with nephrosis. Accordingly, an empirical binding factor for sodium was approximated from the average value found for twenty-five samples of simultaneously obtained serum and ascitic fluid from

\footnotetext{
- Disconnecting the adapter at the needle and allowing two to three drops of blood to flow from the hub prior to inserting the collecting syringe seemed to obviate all but infinitesimal errors of dilution or contamination in serum sodium measurements.
}

six nephrotic children. The determined factor was 1.0. The factor used for potassium was $\mathbf{0 . 8 5}$.

Volume distribution of thiosulfate. This measurement was used as a means of indicating the initial theoretical extracellular volume of distribution of infused sodium. The diffusion from serum of an injected quantity of thiosulfate and its excretion by the kidneys is known to follow the exponential equation $A_{t}=A_{0} e^{-k t}(25,30)$. The initial serum concentration, where $t=0$, was obtained by extrapolation of three corrected serum values, obtained at 30,60 and 90 minutes, to the $y$ intercept $=0$. The volume of distribution (VD) was obtained from the usual relationship:

$$
\text { VD (liters) }=\frac{\left(\mathrm{S}_{2} \mathrm{O}_{2}^{-}\right) \text {injected (grams) }}{\left[\mathrm{S}_{2} \mathrm{O}_{3}^{-}\right]^{\circ}} .
$$

After a single injection of thiosulfate equilibration between serum and ascitic or edematous fluid has been observed in five patients at 90 to 100 minutes. Equilibrium between serum and ascitic, but not edematous, fluid was found in one patient at this time. The apparent volume of distribution of thiosulfate may not represent the total extracellular water.

\section{RESULTS}

Partial protocols of the observed data for one normal and one nephrotic child are recorded in Table I. The absence of acidosis or azotemia and details of specific renal functions before, during, and after ACTH therapy are indicated in Table II. The essential data relative to sodium and potassium excretion are summarized in Table IV and Figures 1 and 2.

\section{Renal functions}

Glomerular filtration rates were definitely reduced in two of the four nephrotic children prior to therapy. After diuresis the reduced filtration rates were somewhat improved. The filtration fraction, which was reduced prior to therapy in three of the four nephrotic children, was within normal limits in all of the children following diuresis. TmPAH did not follow a consistent pattern. GFR/Tm ratios were rather uniformly reduced and did not change significantly with diuresis. $\mathrm{RPF} / \mathrm{Tm}$ ratios tended toward low normal values and were not consistently altered with diuresis.

Neither acidosis nor azotemia were present in these patients. A mild alkalosis was present in each of the nephrotic patients at the end of ten days of ACTH therapy. Slight to marked hypokaliemia was also noted at this time. Serum pro-

7 The signs ( ) and [ ] denote total quantity and concentration of solute per liter of $\mathrm{H}_{2} \mathrm{O}$, respectively. 
JACK METCOFf, NObUYUki NAKASONe, AND C. PHILlips RANCE

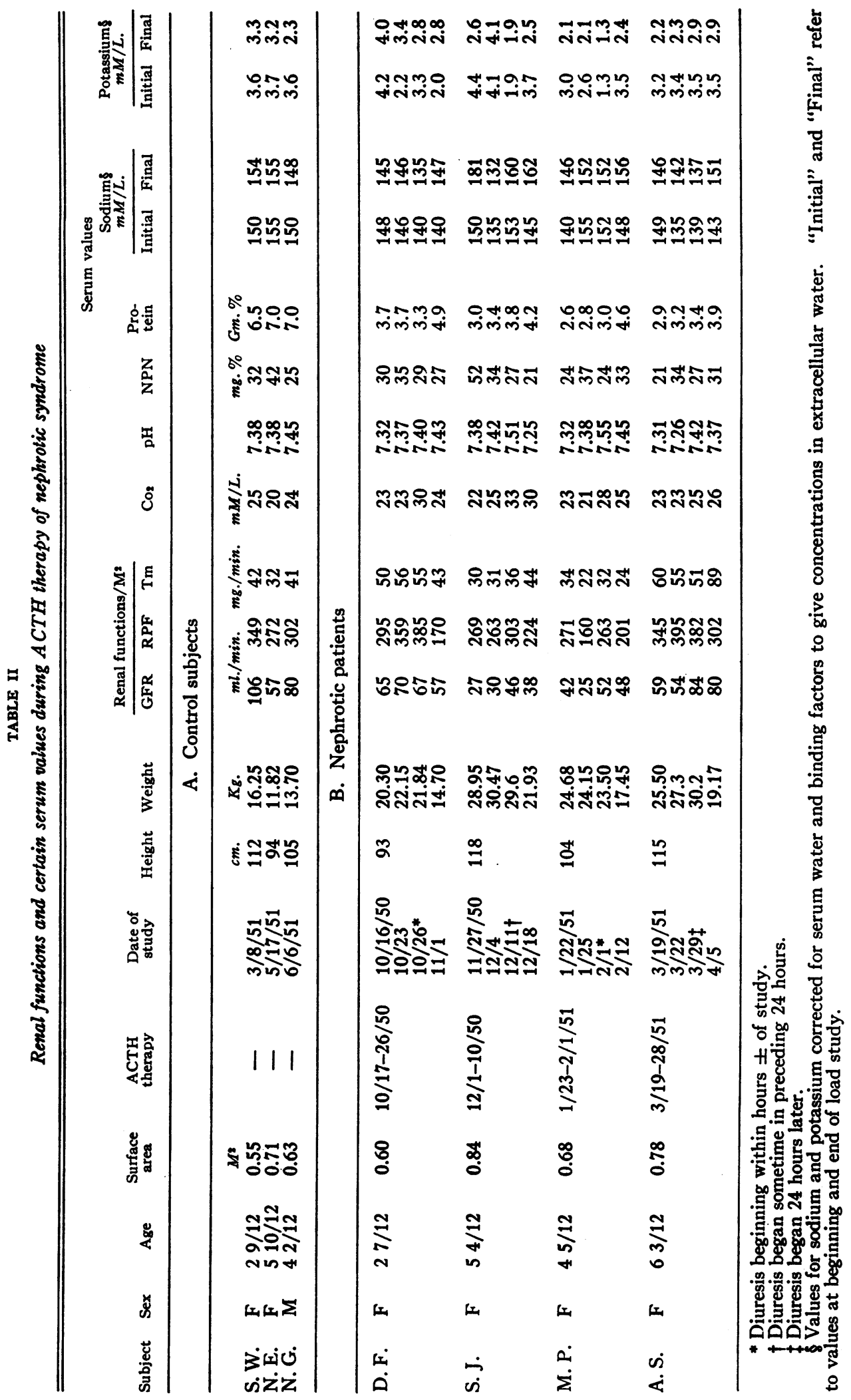


TABLE III

Average sodium retention during load study

\begin{tabular}{lccc}
\hline \multicolumn{1}{c}{ Subjects } & Infused & Excreted & Retained \\
\hline 3 "Normal" children & 203 & 92 & $\%$ \\
Nephrotics: & & & 55 \\
Before ACTH & 140 & 30 & \\
During ACTH & 153 & 23 & 79 \\
Onset diuresis & 173 & 74 & 85 \\
After diuresis & 170 & 92 & 57 \\
& & & \\
\hline
\end{tabular}

teins were uniformly low prior to and during therapy. Some increase was noted when the patients were non-edematous after seven to ten days of diuresis.

\section{Solute diuresis}

In the control individual, urine flows directly proportional to excretion of non-reabsorbed solutes are one feature of solute diuresis (13). This was true also in the edematous nephrotic child. In a few experiments $\mathrm{NH}_{4}{ }^{+}$and $\mathrm{HPO}_{4}=$ excretion were measured and either decreased or remained unchanged. Titratable acidity was not measured. Urinary $\mathrm{pH}$ was usually under 6.0 . It was not observed to exceed 6.26 with the sodium loads. The excretion of sodium + potassium was roughly equivalent to that of the non-reabsorbable anion + chloride at all levels of solute excretion.

\section{Sodium excretion}

In the control subjects, the rate of sodium excretion increased approximately five to seven fold during infusion of the load (Table I). Approximately half of the infused sodium was excreted during the period of loading (Table III).

TABLE IV

Cumulative excretion* of filtered sodium (corrected) † and potassium per square meter surface area

\begin{tabular}{|c|c|c|c|c|c|c|c|c|}
\hline \multirow[b]{2}{*}{ Subject } & \multirow[b]{2}{*}{ Date } & \multirow[b]{2}{*}{ Time } & \multirow{2}{*}{$\underset{\mathrm{Na}}{\text { Infused }}$} & \multicolumn{3}{|c|}{ Filtered } & \multicolumn{2}{|c|}{ Excreted } \\
\hline & & & & $\overline{\mathrm{H}_{2} \mathrm{O} t}$ & $\mathrm{Na}$ ot & $\overline{K 8}$ & $\mathrm{Na}$ & $\mathbf{K}$ \\
\hline
\end{tabular}

A. Normal subjects

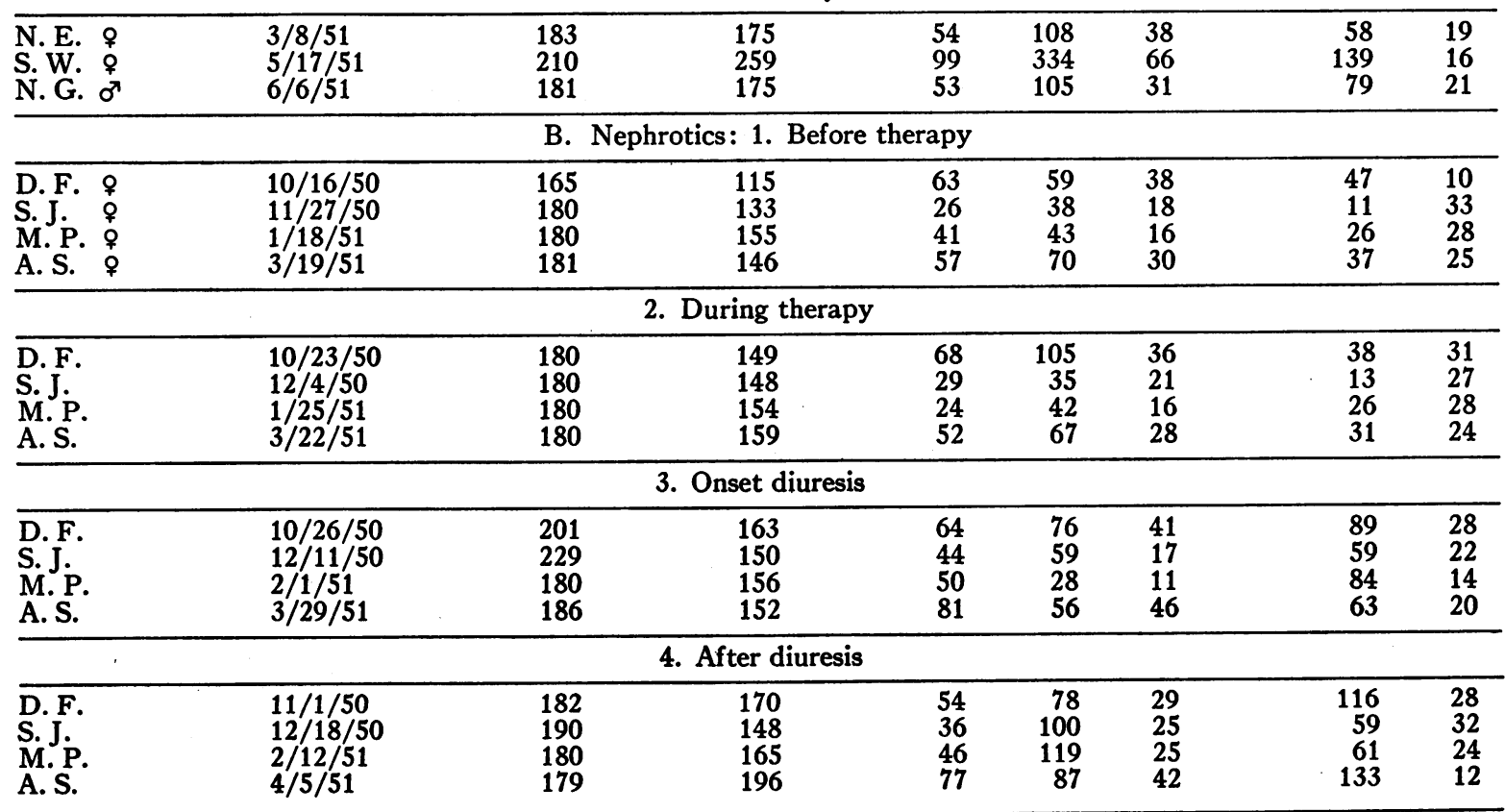

* Additive values for electrolyte excretion in 10 consecutive clearance and collection periods.

t Filtered $\mathrm{Na}_{0}$ refers to the infused $\mathrm{Na}$, corrected for its diffused volume of distribution, which is filtered. It is determined by calculation (31). This correction is used in order to account for the effect of edema on the acute load responses.

$\ddagger$ Filtered $\mathrm{H}_{2} \mathrm{O}=\mathrm{GFR} \times\left[\right.$ Serum $\left.\mathrm{H}_{2} \mathrm{O}\right]$.

Filtered $\mathrm{K}=[\mathrm{K}]_{\text {morum }} \times 0.85 \times \mathrm{GFR}$. 


\section{COMPARISON OF NEPHROTIC TO NORMAL SODIUM} LOAD RESPONSE*

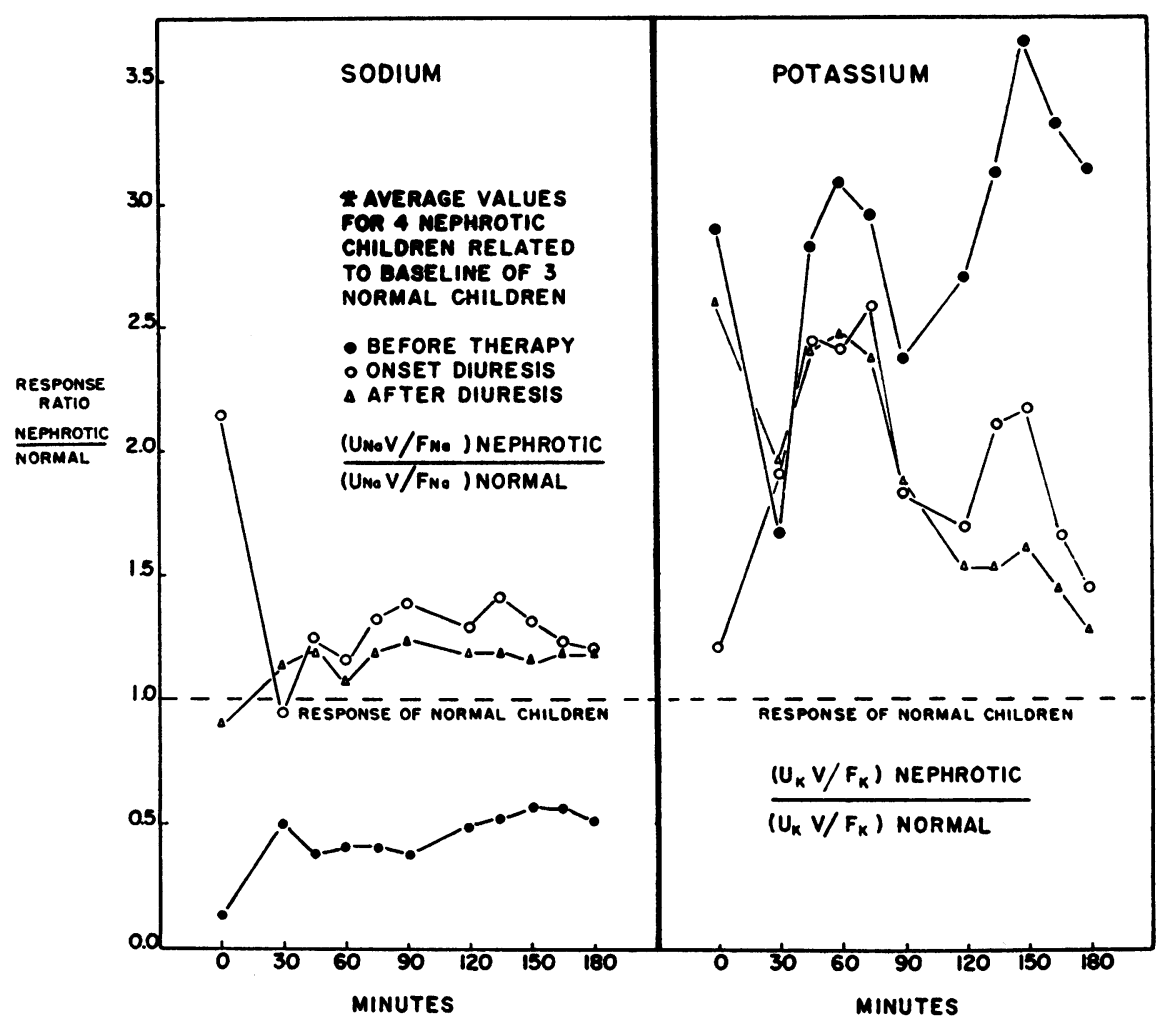

Fig. 1. The Average Ratio of the Quantity of Electrolyte Excreted Per Minute to the Quantity Filtered per Minute by Three "Normal" Control Children during the Sodium Loads Is Taken as a Point of Reference and Indicated as a Dashed Baseline Extending from the Ordinate Value of 1.0

Similar ratios, derived from data on the four nephrotic children, are compared to the control subjects' response. The relative excretion of filtered sodium by the nephrotic children is impaired during edema before therapy, but is at least equivalent to the controls' response at the onset of and after diuresis. In contrast to the sodium excretion response, the relative excretion of potassium by the nephrotic children, irrespective of the state of edema, was greater than that of the "normal" subjects. When filtered potassium excretion of the nephrotic subjects exceeded that of the control subjects by a ratio of about 1.5 , potassium secretion usually was present in the nephrotic children.

In the edematous nephrotic patients prior to ACTH therapy and during infusion of the load, the increased rate of sodium excretion was much greater than in the control subjects owing to the extremely low initial value. The quantity of sodium excreted, however, was considerably less than in the control. The proportion of the total filtered sodium excreted per unit time was about two-thirds of that observed in the control subjects (Figure 1). Less than one-fourth of the infused sodium was excreted during the period of loading (Table III). This relative sodium retention during the three-hour study was not solely the result of excessive tubular reabsorption, since dilution of the infused sodium load in a very large volume of edema fluid reduced the quantity presented for filtration during the initial periods of the study.

Following the first few days of ACTH therapy, retention of the infused sodium load was slightly increased (Table III).

Diuresis began in the nephrotic patients a few 
to 24 hours before the end of the ten-day course of ACTH therapy. An attempt was made to initiate load studies either immediately prior to or within a few hours after diuresis began. With the onset of diuresis, when sodium excretion was abundant, there was a less striking increase (two to four fold) in the rate of sodium excretion during loading. The infused sodium load was ex-

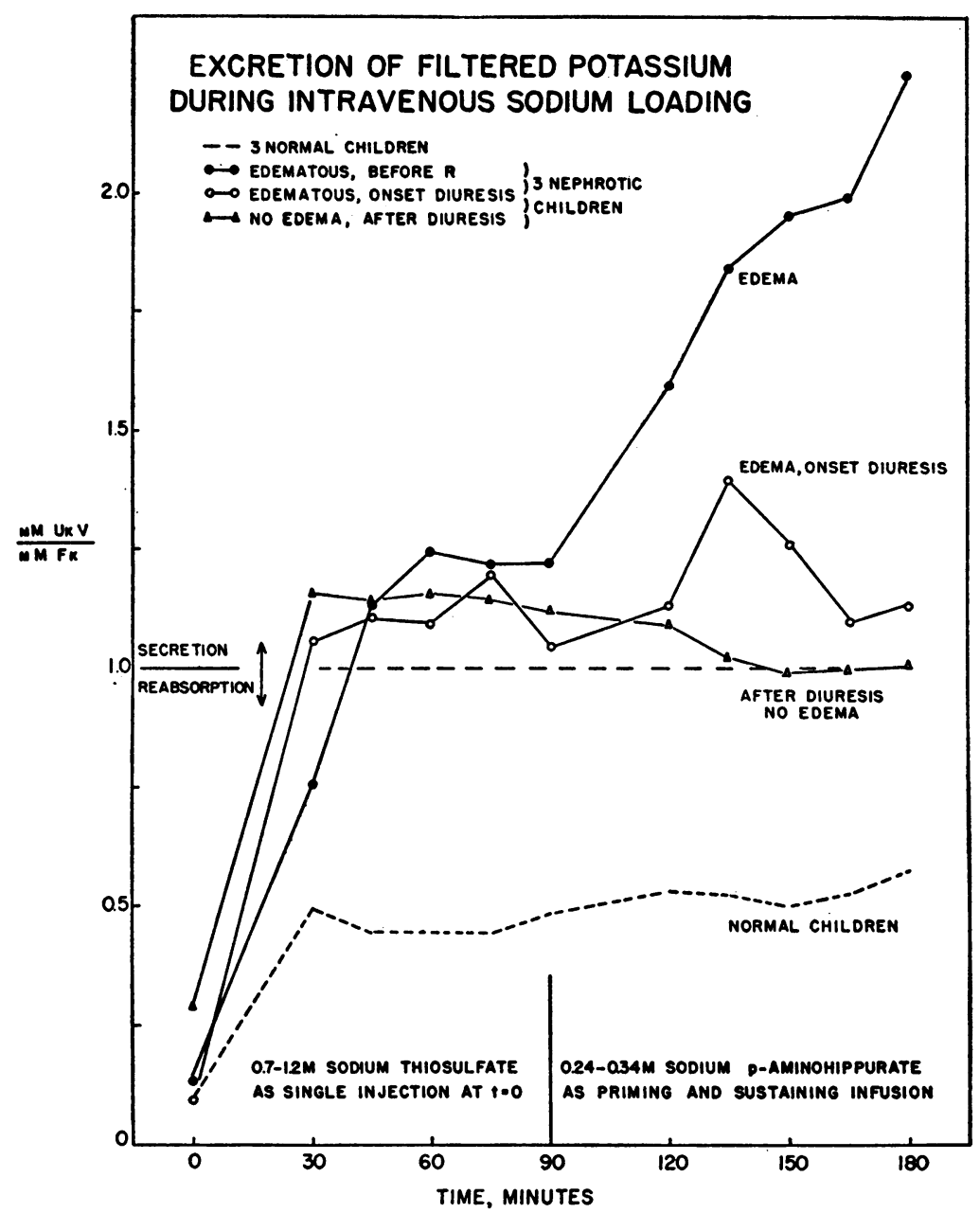

Fig. 2. This Chart Shows the Usual Patterns of Potassium SecreTION DURING THe Sodium LoAdS

Potassium secretion was not observed in any period in three of the sixteen load studies. These particular studies (D.F. prior to therapy, A.S. at the onset of diuresis and after diuresis) therefore were not included in this chart.

The dashed line from the ordinate value of 1.0 represents the point at which the rate of potassium excretion is equal to that filtered. Relative values below this line, therefore, indicate net reabsorption of filtered potassium. Relative values above the line indicate excretion of potassium in excess of quantities simultaneously filtered, i.e., secretion of potassium. The loading solutes are noted at the bottom of the chart.

The averaged data for each period in thirteen of the sixteen studies indicate that potassium secretion in the nephrotic patients commonly results from infusion of the hypertonic sodium load, irrespective of the state of edema. Although increased excretion of potassium occurs in the "normal" control subjects in response to similar loads, potassium secretion was not observed. 
creted as rapidly as it was filtered ${ }^{8}$ (Table IV) and net retention attributable to reabsorption of that portion of the load which was filtered no longer occurred. Glomerular filtration rate was increased in three out of four patients at the onset of diuresis. The proportion of filtered sodium excreted per unit time was equivalent to that observed in the normal subjects (Figure 1).

Similar results obtained following diuresis, when the nephrotic children were non-edematous. At this time, the net retention of the infused sodium load was less than that observed in the same patients at the onset of diuresis, or in normal subjects (Table III).

\section{Potassium excretion}

In the control subjects, potassium excretion was increased three to five times during the hypertonic sodium loads, as previously demonstrated (11-13, 18). Quantitatively, the level of potassium excretion was about one-third to one-fifth that of sodium (Table I). During the sodium load, 40 to 60 per cent of the filtered potassium was excreted. Excretion of potassium in amounts greater than those simultaneously filtered was not observed in any of the 30 load periods.

Prior to therapy, with the exception of one patient (D.F.), the pattern of excretion of potassium by the edematous nephrotic children during the hypertonic sodium loads differed from that observed in normal subjects. In three of the four patients, a 10 to 40 fold increment in potassium excretion was observed. ${ }^{9}$ In these instances the

\footnotetext{
8 In order to compare the acute renal response of edematous and non-edematous subjects to infused substances which are distributed largely in the extracellular fluid, it is necessary to devise some correction for the edema. A method by which this may be achieved has been described (31) and was used to calculate the quantity of the infused sodium load filtered by the kidney per unit time. This small quantity of sodium represents only a part of the total filtered sodium per unit time. It is the product of the virtual concentration of the infused sodium which is retained in the extracellular fluid and the rate of glomerular filtration of water. The total filtered sodium, of course, is the product of the total concentration of sodium in the extracellular fluid and the rate of glomerular filtration of water.

- Similar results have been obtained in six other nephrotic children. Unpublished data obtained in previous studies (12) indicate that the urinary $K / N$ ratios were considerably greater than 3 during and immediately following the loads.
}

excretion of potassium was, on the average, equivalent to that of sodium (Table IV). Potassium excretion exceeded amounts simultaneously filtered in most periods (Figure 2); however, as indicated in Table IV, the total cumulative excretion of potassium was not always greater than the total amount filtered during the entire three hours of the study. Potassium secretion (32) was greatest in the patients with lowest filtration rates and was likely to occur even when extracellular fluid concentrations of potassium were extremely low, as shown in Table I. In the post-diuresis phase in this patient (M.P.), potassium secretion ceased as the filtration rate rose during the study. Per unit quantity of potassium filtered, the nephrotic patients excreted two to three times more than did the control subjects (Figure 1).

During ACTH therapy, similar but further exaggerated potassium excretion responses were noted in all nephrotic patients.

With the onset of diuresis, excretion of potassium in amounts greater than those simultaneously filtered continued in most periods in three of the four patients, in spite of abundant sodium excretion and elevated glomerular filtration rates. Per unit quantity of potassium filtered, the nephrotic patients excreted approximately 1.5 to 2 times that observed in the normal children.

Some days later, similar results were obtained in the non-edematous state in three of the four patients (Table IV, Figure 2) despite recovery of a normal pattern of sodium excretion (Figure 1). ${ }^{10}$ In all, potassium secretion was elicited by sodium loads in 88 of 155 load periods in thirteen of the sixteen studies on nephrotic patients. In one of four studies in one patient (D.F.) and two of four in another (A.S.) potassium secretion was not caused by the sodium loads.

In both normal and nephrotic subjects, the amount of potassium excreted was greater than could result from the decrease in potassium content in the extracellular fluid. A considerable portion of the excreted potassium therefore appeared to be replaced by extrusion of potassium from the intracellular phase ${ }^{11}$ and accompanied

\footnotetext{
10 Total circulating plasma proteins (total protein times plasma volume ( $T-1824)$ ) were increased and urinary protein excretion was decreased at this time.

11 Calculations such as these are limited by the assumption that the infused sodium remains largely in the ex-
} 
TABLE V

Estimated change of intracellular potassium and water during solute load *

\begin{tabular}{|c|c|c|c|c|c|c|c|c|c|}
\hline \multirow[b]{2}{*}{ Pt. } & \multirow[b]{2}{*}{$\Delta \mathbf{W}^{\mathbf{1}}$} & \multicolumn{4}{|c|}{ Extracellular } & \multirow[b]{2}{*}{$U_{k} V^{*}$} & \multicolumn{3}{|c|}{ Intracellular } \\
\hline & & $\mathrm{H}_{2} \mathrm{O}_{2}$ & $\Delta \mathrm{H}_{8} \mathrm{O}^{3}$ & $(\mathrm{~K})^{4}$ & $\Delta \mathrm{K}^{\mathbf{b}}$ & & $\mathrm{H}_{2} \mathrm{O}^{7}$ & $\Delta \mathrm{H}_{2} \mathrm{O}^{8}$ & $\Delta \mathrm{K}^{\bullet}$ \\
\hline & Kg. & $L$. & $L$. & $m M$ & $m M$ & $m M$ & $L$. & $L$ & $m^{2} M$ \\
\hline \multicolumn{10}{|c|}{ A. Normal subjects } \\
\hline $\begin{array}{l}\text { N. E. } \\
\text { S. W. } \\
\text { N. G. }\end{array}$ & $\begin{array}{r}-0.10 \\
+0.33 \\
+0.28\end{array}$ & $\begin{array}{l}4.96 \\
2.73 \\
4.04\end{array}$ & $\begin{array}{r}+0.45 \\
+0.33 \\
+0.42\end{array}$ & $\begin{array}{r}18.5 \\
9.9 \\
14.7\end{array}$ & $\begin{array}{l}-1.3 \\
0 \\
-\quad 2.5\end{array}$ & $\begin{array}{r}15.7 \\
9.8 \\
14.1\end{array}$ & $\begin{array}{l}4.49 \\
4.28 \\
4.01\end{array}$ & $\begin{array}{c}-0.55 \\
0 \\
-0.14\end{array}$ & $\begin{array}{r}-14.4 \\
-9.8 \\
-11.6 \\
\end{array}$ \\
\hline \multicolumn{10}{|c|}{ B. Nephrotics: 1. Before therapy } \\
\hline $\begin{array}{l}\text { D. F. } \\
\text { S. J. } \\
\text { M.P. } \\
\text { A. S. } \\
\text { L. J. }\end{array}$ & $\begin{array}{c}+0.31 \\
+\overline{0} .17 \\
+0.30 \\
+0.40\end{array}$ & $\begin{array}{l}5.54 \\
9.54 \\
9.02 \\
9.46 \\
9.02\end{array}$ & $\begin{array}{r}+0.25 \\
-1.08 \\
+0.19 \\
+0.81 \\
+1.25\end{array}$ & $\begin{array}{l}23.4 \\
41.9 \\
27.4 \\
30.2 \\
31.7\end{array}$ & $\begin{array}{r}-0.4 \\
-19.9 \\
-\quad 8.1 \\
=\quad 7.6 \\
-6.5\end{array}$ & $\begin{array}{r}4.6 \\
30.6 \\
20.2 \\
19.8 \\
28.7\end{array}$ & $\begin{array}{l}6.13 \\
6.91 \\
5.07 \\
5.09 \\
3.03\end{array}$ & $\begin{array}{c}+0.06 \\
-\overline{0.02} \\
-0.23 \\
-0.41\end{array}$ & $\begin{array}{l}-4.2 \\
-10.7 \\
-12.1 \\
-12.2 \\
-22.2 \\
\end{array}$ \\
\hline \multicolumn{10}{|c|}{ 2. During therapy } \\
\hline $\begin{array}{l}\text { D. F. } \\
\text { S. J. } \\
\text { M.P. } \\
\text { A. S. } \\
\end{array}$ & $\begin{array}{c}+0.10 \\
+0.04 \\
+0.05 \\
0\end{array}$ & $\begin{array}{r}5.17 \\
11.56 \\
9.22 \\
9.46\end{array}$ & $\begin{array}{r}+0.47 \\
+1.13 \\
+0.84 \\
+0.20\end{array}$ & $\begin{array}{l}11.4 \\
46.9 \\
23.8 \\
31.7 \\
\end{array}$ & $\begin{array}{r}+7.8 \\
+4.6 \\
+3.1 \\
-9.5\end{array}$ & $\begin{array}{l}18.6 \\
22.6 \\
13.3 \\
21.5\end{array}$ & $\begin{array}{l}7.53 \\
5.70 \\
4.58 \\
6.05\end{array}$ & $\begin{array}{r}-0.37 \\
-1.09 \\
-0.79 \\
-0.20\end{array}$ & $\begin{array}{l}-26.4 \\
-27.2 \\
-10.2 \\
-12.0\end{array}$ \\
\hline \multicolumn{10}{|c|}{ 3. Onset of diuresis } \\
\hline $\begin{array}{l}\text { D. F. } \\
\text { S. J. } \\
\text { M.P. } \\
\text { A. S. }\end{array}$ & $\begin{array}{r}-0.46 \\
-\overline{0.20} \\
+0.16\end{array}$ & $\begin{array}{r}6.21 \\
9.55 \\
8.68 \\
12.28\end{array}$ & $\begin{array}{r}+0.59 \\
+0.07 \\
+0.12 \\
+0.61\end{array}$ & $\begin{array}{l}20.7 \\
17.8 \\
11.5 \\
43.0\end{array}$ & $\begin{array}{r}-5.3 \\
+0.2 \\
+0.1 \\
-5.6\end{array}$ & $\begin{array}{r}17.1 \\
18.6 \\
9.4 \\
15.3\end{array}$ & $\begin{array}{l}6.30 \\
6.74 \\
4.24 \\
4.83\end{array}$ & $\begin{array}{l}-1.05 \\
-\overline{0.32} \\
-0.45\end{array}$ & $\begin{array}{r}-11.8 \\
-18.8 \\
-\quad 9.5 \\
-9.7\end{array}$ \\
\hline \multicolumn{10}{|c|}{ 4. After diuresis } \\
\hline $\begin{array}{l}\text { D. F. } \\
\text { S. J. } \\
\text { M. P. } \\
\text { A. S. }\end{array}$ & $\begin{array}{c}-0.18 \\
0 \\
+0.03 \\
-0.44\end{array}$ & $\begin{array}{l}3.98 \\
5.70 \\
4.10 \\
5.44\end{array}$ & $\begin{array}{r}+0.02 \\
-0.49 \\
+0.21 \\
-0.12\end{array}$ & $\begin{array}{r}8.0 \\
20.9 \\
14.2 \\
19.0\end{array}$ & $\begin{array}{l}+3.4 \\
-8.1 \\
-3.7 \\
-3.6\end{array}$ & $\begin{array}{r}16.6 \\
26.6 \\
16.5 \\
9.7\end{array}$ & $\begin{array}{l}4.61 \\
6.87 \\
6.00 \\
5.62\end{array}$ & $\begin{array}{l}-0.20 \\
+0.49 \\
-0.18 \\
-0.32\end{array}$ & $\begin{array}{l}-20.0 \\
-18.5 \\
-12.8 \\
-6.1\end{array}$ \\
\hline
\end{tabular}

* $1 \Delta \mathrm{W}=$. change in body weight during load study.

2 Extracellular water is taken as the volume of distribution of thiosulfate.

s $\Delta \mathrm{H}_{2} \mathrm{O}$ (extracellular) is derived from the initial value, sodium balance and change in corrected serum [Na], during the load, after the method of Darrow (46).

$(\mathrm{K})=$ extracellular $\mathrm{K}$ derived from initial $\mathrm{H}_{2} \mathrm{O}_{\mathrm{ECW}} \times$ corrected serum $[\mathrm{K}]$.

$\checkmark \Delta \mathrm{K}$ (extracellular) is final $\mathrm{H}_{2} \mathrm{O}_{\mathrm{ECW}} \times$ corrected serum $[\mathrm{K}]$.

- $\mathrm{U}_{\mathbf{k}} \mathrm{V}$ refers to total urinary potassium excretion.

7 Intracellular water = total body water $-\mathrm{ECW}$. TBW calculated as $\mathrm{BW}=\left(\mathrm{W}_{\mathrm{Kg}} \times 0.55\right)+0.51(47)$.

${ }^{8} \Delta \mathrm{H}_{2} \mathrm{O}$ (intracellular) $=\Delta \mathrm{W}-\Delta \mathrm{H}_{2} \mathrm{O}_{\mathrm{ECW}}$.

$\Delta \mathrm{K}$ (intracellular) $=\left(-\mathrm{U}_{\mathrm{k}} \mathrm{V}\right)-\left(\Delta \mathrm{K}_{\mathrm{ECW}}\right)$.

by removal of intracellular water (Table $\mathrm{V})$, as previously noted $(17,18,33)$.

There was no consistent relation between concentration of potassium in the extracellular fluid; its preferential removal from either the extra- or intracellular compartments, and the occurrence of renal tubular secretion of this ion. In general, the nephrotic patients developed lower potassium concentrations in the extracellular fluid. In the untreated edematous state, an amount equivalent to

tracellular fluid during the two to three hour period of observation. If some infused sodium entered the cells during the interim, the quantity of potassium removed from the intracellular fluid, as calculated, would be greater. about half of the excreted potassium was withdrawn from the intracellular fluid (Table VI). During ACTH therapy, without significant change in edema, an amount equivalent to virtually all of the excreted potassium appeared to be removed from the intracellular compartment. Hence no change in potassium content of the extracellular fluids was noted. With the onset of diuresis despite continued ACTH therapy, and with little evident change in edema and relative extracellular alkalosis, the contributions of the intracellular phases to the extracellular fluids to replenish excreted potassium seemed similar to those of the normal subjects. This was true also in the postdiuresis studies. 
TABLE VI

Average change* in potassium content of body fluids with sodium load and potassium excretion

\begin{tabular}{|c|c|c|}
\hline \multirow[b]{2}{*}{ Subjects } & \multicolumn{2}{|c|}{ Potassium balance } \\
\hline & Extracellular & Intracellula \\
\hline & \multicolumn{2}{|c|}{$m M / M^{2}$} \\
\hline Normals & -2 & -18 \\
\hline \multicolumn{3}{|l|}{ Nephrotics: } \\
\hline $\begin{array}{l}\text { Before Rx } \\
\text { During Rx } \\
\text { Onset diuresis } \\
\text { After diuresis }\end{array}$ & $\begin{array}{r}-12 \\
0 \\
-\quad 4 \\
-4\end{array}$ & $\begin{array}{l}-14 \\
-27 \\
-17 \\
-21\end{array}$ \\
\hline
\end{tabular}

* These data represent averaged values of observations in Table $\mathrm{V}$ corrected to unit surface area.

\section{Water excretion}

"Normal" children excreted 3 to $5 \mathrm{ml}$. of water per $100 \mathrm{ml}$. of glomerular filtrate during the solute load.

The fraction of filtered water excreted by the untreated edematous nephrotic children in the preloading periods was approximately one-third that of the normal subjects. With the induction of the intravenous solute load, the proportion of filtered water excreted doubled and averaged 75 to 85 per cent of that observed in the normal children. A dissociation in relative excretions of sodium and water in response to the loads therefore was evident. This phenomenon has been noted with other types of solute diuresis (34).

With the onset of diuresis, and in the non-edematous state thereafter, the nephrotic subjects excreted 5 to $8 \mathrm{ml}$. water per $100 \mathrm{ml}$. glomerular filtrate during the solute loads.

\section{DISCUSSION}

The data reveal that "normal" children and nephrotic children respond to two sodium nonreabsorbable anion loads in distinctly different ways, the difference lying principally in the handling of potassium rather than of sodium.

The excretion of sodium, infused as hypertonic $\mathrm{Na}_{2} \mathrm{~S}_{2} \mathrm{O}_{8}$ and $\mathrm{NaPAH}$, by the control subjects was comparable to excretions observed during infusions of hypertonic $\mathrm{NaCl}$ loads in adults (35). During accumulating edema the nephrotic patients (except D.F.) excreted considerably less of the sodium load than did the normal subjects during the short period of observation. The re- duced excretion of sodium at this time is consistent with the concept of glomerulo-tubular imbalance $(9,10)$. However, since the infused sodium load is distributed in a much larger diffusion volume in the edematous patient, turnover is slower and less of the infused load is filtered per unit time; thus a lesser amount of the injected load is available for excretion during the relatively short time of study. Diffusion into the edema fluid, augmented by the diminished serum oncotic pressure represents a peripheral effect on net sodium retention and is in accord with the "oncotic hypothesis" $(2,3)$.

At the onset of diuresis before there was appreciable change in edema or hypoproteinemia, ${ }^{12}$ sodium load excretion became entirely normal. Glomerular filtration rates tended to increase ; ${ }^{18}$ however if glomerulo-tubular "imbalance" (10) is reflected in the GFR/Tm ratio, then glomerulotubular "imbalance" persisted at this time and after diuresis was completed, although marked diminution of sodium reabsorption was observed. The rapidity with which the pattern of renal sodium exchange reverted to normal was striking. If the basic defect was in sodium excretion due to glomerulo-tubular imbalance and/or excessive elaboration of a specific sodium retaining hormone, then these presumably no longer obtained. Since renal tubular potassium secretion persisted at this time (except in A. S.) and did not occur in the normal individuals under similar circumstances, a cellular defect in retention or transport of this essential intracellular ion appears possible. In the nephrotic syndrome, renal tubular potassium secretion is apparently not dependent upon increased sodium reabsorption. Return to normal patterns of potassium exchange appeared delayed for longer than the period of study, i.e., more than five to

12 It is possible, but unlikely, that specific plasma albumin concentration had increased and concentration of the alpha and beta globulins had decreased proportionately with net increase in oncotic pressure but without change in total protein concentration.

18 The improved filtration rate and filtration fraction with ACTH therapy $(21,36)$ may result from improvement in the thickened glomerular basement membrane, which appears to be a primary lesion in the nephrotic syndrome $(22,37,38)$. With an improvement in this lesion, diminished glomerular permeability to albumin has been reported (10). The consequent sparing of plasma protein not only increased oncotic pressure, but undoubtedly replenished the depleted cellular protein stores. 
seven days following onset of diuresis. Intracellular potassium accretion in amounts relatively greater than nitrogen and extrusion of significant quantities of intracellular sodium have been noted with successful adrenocorticotropin (ACTH) therapy (39).

The oncotic and glomerulo-tubular imbalance hypotheses contribute important descriptions of phenomena associated with edema. They do not account however for those mechanisms which cause the kidney tubular cell to regulate the reabsorption of sodium during edema and diuresis in the nephrotic syndrome. Variations in secretion of a specific sodium-retaining steroid by the adrenal cortex could account directly for alterations in sodium excretion (40). With predominant emphasis on sodium reabsorption, renal removal of an infused sodium plus non-reabsorbable anion load would obligate excessive potassium excretion. But why should such a hormone be elaborated in the nephrotic syndrome or by individuals on low sodium diets (41)? Further, a predominant effect on sodium reabsorption would not explain excessive potassium excretion during sodium diuresis, unless anion excretion was the primary determinant of urine composition during diuresis.

There are too many gaps in current knowledge to resolve the complex interrelationships characterizing nephrotic edema in a completely satisfactory way. However, proceeding from the premise that a cellular defect, as suggested by the load studies, as well as a glomerular membrane lesion characterizes the nephrotic syndrome, reorientation of the available data offers certain attractive features. For example, following primary immunogenic insult a glomerular membrane lesion $(37,38)$ would result in the characteristic loss of plasma albumin and diminished capillary oncotic pressure $(2,3)$. The decreased plasma volume attending plasma albumin depletion (42) might favor elaboration of antidiuretic substances (10) which induce renal retention of water. Assuming utilization of intracellular protein to replace plasma protein losses, the resulting protein deficit would be expected to release a corresponding quantity of potassium which would be removed immediately by the kidney (43). In the presence of peripheral water retention caused by reduction of oncotic pressure and on the premise of osmolar equality of intra- and extracellular fluids, reduction of os- molarity of both fluids is inevitable ${ }^{14}$ unless the solute concentration of extracellular fluid can be raised. Retention of sodium obviously serves this end. Osmolar equality would be preserved either by transfer of intracellular water to the extracellular compartment or by entrance of sodium into cell fluids. According to this sequence of events, the loss of potassium and the retention of sodium can be traced to deficit of protein through the glomerulus.

However, certain observed features of the loss of potassium indicate that this process is not entirely incidental to loss of intracellular protein. For example, this sequence would not account for the ready loss of potassium in response to sodium loading during the post diuresis phase when proteinuria was decreased and circulating plasma protein was increased. Other load studies during edema have shown that when potassium is lost, the loss is in excess of nitrogen, thus suggesting depletion of intracellular potassium. The behavior of potassium under the conditions of these experiments suggests that other disturbances in the organization of cell fluid and electrolyte transport besides loss of protein are operative. The evidence suggests that these disturbances have an important position in the pathogenesis of edema in the nephrotic syndrome.

In the presence of 1) depletion of plasma and intracellular protein, 2) disturbance of cell solute control permitting excessive outgo of potassium, and 3) water retention from reduction of plasma oncotic pressure, the kidney appears to remove potassium rapidly in defense of the plasma potassium concentration and withhold sodium to support body fluid osmolarity. In this view the altered patterns of renal tubular function observed in the nephrotic syndrome may be regarded as defensive adjustments to glomerular, cellular, and hemodynamic disturbances.

\section{SUMMARY}

1. The responses to intravenous infusions of hypertonic sodium plus non-reabsorbable anion loads were compared in four nephrotic and three control children during accumulating edema, at the

\footnotetext{
14 Some such readjustment could account for the observed hypotonicity of extracellular fluid in the nephrotic syndrome $(9,44,45)$.
} 
onset of diuresis induced by ACTH therapy, and after diuresis was completed.

2. Excretion of the infused sodium load was impaired during accumulating edema. It was equivalent to or better than that of the control children at the onset and after completion of diuresis.

3. Excessive excretion of potassium, usually in amounts greater than simultaneously filtered was observed in the nephrotic children, not in the controls.

4. This excessive excretion of potassium was elicited at the onset and after completion of diuresis despite improved glomerular filtration rates and essentially normal sodium excretion. The excessive excretion with secretion of potassium in the nephrotic syndrome appeared, therefore, to be independent of sodium reabsorption.

5. A significant proportion of the potassium removed from the extracellular fluid and excreted in the urine was provided by or promptly replaced from the intracellular phase, according to calculation.

6. These observations suggest that renal tubular reabsorption of sodium and excretion of potassium in the nephrotic syndrome may represent a homeostatic kidney response, rather than a disturbance of function; namely, a response to a reversible cell defect favoring potassium loss and indirectly conditioning sodium retention. In this view defective kidney tubule function with reference to sodium is not present.

7. A sequence of events is suggested which relates the glomerular membrane lesion and possible changes in the organization of cellular fluids to the decreased oncotic pressure and the retention of sodium and water which result in edema.

\section{ACKNOWLEDGMENT}

We are particularly indebted to Dr. J. L. Gamble for many stimulating comments and helpful suggestions in preparation of the manuscript.

\section{REFERENCES}

1. Starling, E. H., On the absorption of fluids from the connective tissue spaces. J. Physiol., 1896, 19, 312.

2. Epstein, A. A., Concerning the causation of edema in chronic parenchymatous nephritis: Method for its alleviation. Am. J. M. Sc., 1917, 154, 638.

3. Loeb, R. F., Atchley, D. W., Richards, D. W., Jr., Benedict, E. M., and Driscoll, M. E., On the mechanism of nephrotic edema. J. Clin. Invest., 1932, 11, 621.

4. Widal, F., and Javal, A., La chlorurémie et la cure de déchloruration dans le mal de Bright. Etude sur l'action déchlorurante de quelques diurétiques. Presse médicale, 1903, 2, 701.

5. Magnus-Levy, A., Natrium-und Kaliumsalze bei Wassersucht. Ztschr. f. Klin. Med., 1928, 107, 659.

6. Blum, L., and Van Caulaert, C., Le rôle du sel dans les néphrites; étude clinique physiopathologique et thérapeutique, avec la collaboration de P. S. Pétrequin. Paris, Masson et Cie, 1931, p. 292.

7. Hoffman, W. S., and Post, W. E., The influence of mineral metabolism upon nephrotic edema. J. Clin. Invest., 1933, 12, 613.

8. Albright, F., and Bauer, W., The action of sodium chloride, ammonium chloride, and sodium bicarbonate on the total acid-base balance of a case of chronic nephritis with edema. J. Clin. Invest., 1929, 7, 465.

9. Bradley, S. E., and Tyson, C. J., The "Nephrotic Syndrome." New England J. Med., 1948, 238, 223, 260.

10. Barnett, H. L., Forman, C. W., and Lauson, H. D., The Nephrotic Syndrome in Children in Advances in Pediatrics, New York, Year Book Publishers, Inc., 1952, v.

11. Burnett, C. H., Burrows, B. A., and Commons, R. R., The lack of correlation between glomerular filtration rate, and serum electrolyte concentration changes, urinary electrolyte excretion, or edema formation following sodium loads in subjects with normal kidneys, glomerulonephritis, and the nephrotic syndrome. J. Clin. Invest., 1949, 28, 773.

12. Metcoff, J., and Wallace, W. M., The nephrotic syndrome in children: Response to intravenous sodium loads. J. Clin. Invest., 1950, 29, 835.

13. Rapoport, S., Brodsky, W. A., West, C. D., and Mackler, B., Urinary flow and excretion of solutes during osmotic diuresis in hydropenic man. Am. J. Physiol., 1949, 156, 433.

14. Rapoport, S., and West, C. D., Ionic antagonism: Effect of various anions on chloride excretion during osmotic diuresis in the dog. Am. J. Physiol., 1950, 162, 668.

15. Smith, H. W., The Kidney: Structure and Function in Health and Disease. New York, Oxford Univ. Press, 1951, p. 1049.

16. Wolf, A. V., The Urinary Function of the Kidney. New York, Grune and Stratton, 1950, p. 363.

17. Elkinton, J. R., and Winkler, A. W., Transfers of intracellular potassium in experimental dehydration. J. Clin. Invest., 1944, 23, 93.

18. Seldin, D. W., and Tarail, R., Effect of hypertonic solutions on metabolism and excretion of electrolytes. Am. J. Physiol., 1949, 159, 160.

19. Fox, C. L., Jr., and Slobody, L. B., Tissue changes in the nephrotic syndrome: Demonstration of potassium depletion. Pediatrics, 1951, 7, 186. 
20. Rapoport, M., McCrory, W. W., Barbero, G., Barnett, H. L., Forman, C. W., and McNamara, H., Effect of corticotrophin (ACTH) on children with the nephrotic syndrome. J. A. M. A., 1951, 147, 1101.

21. Metcoff, J., Rance, C. P., Kelsey, W. M., Nakasone, N., and Janeway, C. A., Adrenocorticotrophic hormone (ACTH) therapy of the nephrotic syndrome in children. Pediatrics, 1952, 10, 543.

22. Metcoff, J., Kelsey, W. M., and Janeway, C. A., The nephrotic syndrome in children. An interpretation of its clinical, biochemical and renal hemodynamic features as variations of a single type of nephron disease. J. Clin. Invest., 1951, 30, 471.

23. Roe, J. H., Epstein, J. H., and Goldstein, N. P., A photometric method for the determination of inulin in plasma and urine. J. Biol. Chem., 1949, 178, 839.

24. Goldring, W., and Chasis, H., Hypertension and hypertensive disease. The Commonwealth Fund, N. Y., 1944, p. 253.

25. Newman, E. V., Gilman, A., and Philips, F. S., The renal clearance of thiosulfate in man. Bull. Johns Hopkins Hosp., 1946, 79, 229.

26. Wallace, W. M., Holliday, M., Cushman, M., and Elkinton, J. R., The application of the internal standard flame photometer to the analysis of biologic material. J. Lab. \& Clin. Med., 1951, 37, 621.

27. Wilson, D. W., and Ball, E. G., A study of the estimation of chloride in blood and serum. J. Biol. Chem., 1928, 79, 221.

28. Van Slyke, D. D., and Neill, J. M., The determination of gases in blood and other solutions by vacuum extraction and manometric measurement. I J. Biol. Chem., 1924, 61, 523.

29. Hastings, A. B., and Sendroy, J., Jr., Studies of acidosis. $\mathrm{XX}$. The colorimetric determination of blood $\mathrm{pH}$ at body temperature without buffer standards. J. Biol. Chem., 1924, 61, 695.

30. Cardozo, R. H., and Edelman, I. S., The volume of distribution of sodium thiosulfate as a measure of the extracellular fluid space. J. Clin. Invest., 1952, 31, 280.

31. Metcoff, J., In proceedings of the 3rd annual conference on the nephrotic syndrome. Dec. 1951.

32. Berliner, R. W., Kennedy, T. J., Jr., and Hilton, J. G., Renal mechanisms for excretion of potassium. Am. J. Physiol., 1950, 162, 348.

33. Mudge, G. H., Foulks, J., and Gilman, A., Renal secretion of potassium in the dog during cellular dehydration. Am. J. Physiol., 1950, 161, 159.

34. Wesson, L. G., Jr., and Anslow, W. P., Jr., Excretion of sodium and water during osmotic diuresis in the dog. Am. J. Physiol., 1948, 153, 465.
35. Crawford, B., and Ludemann, $H .$, The renal response to intravenous injection of sodium chloride solutions in man. J. Clin. Invest., 1951, 30, 1456.

36. Barnett, H. L., Forman, C. W., McNamara, H., McCrory, W. W., Rapoport, M., Michie, A. J., and Barbero, G., The effect of adrenocorticotrophic hormone on children with the nephrotic syndrome. II. Physiologic observations on discrete kidney functions and plasma volume. J. Clin. Invest., 1951, $30,227$.

37. Bell, E. T., Renal Diseases. Philadelphia, Lea \& Febiger, 1946, p. 434.

38. Ehrich, W. E., Forman, C. W., and Seifer, J., Diffuse glomerular nephritis and lipid nephrosis. Correlation of clinical, morphological, and experimental observations. Arch. Path., 1952, 54, 463.

39. James, J. A., and Metcoff, J., On diuresis of nephrotic edema. In Proc. National meeting Am. Fed. Clin. Research, May 1953.

40. Luetscher, J. A., Jr., Deming, Q. B., and Johnson, B. B., Treatment of nephrosis with pituitary adrenocorticotrophin. J. Clin. Invest., 1951, 30, 1530.

41. Luetscher, J. A., Jr., and Johnson, B. B., Chromatographic separation of the sodium-retaining corticoid from the urine of children with nephrosis, compared with observations on normal children. J. Clin. Invest., 1954, 33, 276.

42. Metcoff, J., Favour, C. B., and Stare, F. J., Plasma protein and hemoglobin in the protein-deficient rat. A three-dimensional study. J. Clin. Invest., 1945, 24,82 .

43. Hegsted, D. M., Milner, J. P., Wilson, D., and Ginna, P., Changes in muscle water and composition induced by protein depletion in rat at two environmental temperatures. Am. J. Physiol., 1953, 172, 14.

44. Fox, C. L., Jr., and McCune, D. J., Electrolyte changes in nephrosis: occurrence of diuresis following administration of sodium and potassium salts. Am. J. M. Sc., 1948, 216, 1.

45. Crawford, J. D., Cook, C. D., and Pinkham, B., Observations on body-water concentration homeostasis of children with the nephrotic syndrome. Am. J. Dis. Child., 1953, 84, 754.

46. Darrow, D. C., The retention of electrolyte during recovery from severe dehydration due to diarrhea. J. Pediat., 1946, 28, 515.

47. Friis-Hansen, B. J., Holliday, M., Stapleton, T., and Wallace, W. M., Total body water in children. Pediatrics, 1951, 7, 321. 